J. Appl. Glycosci., 53, 45-49 (2006)

(C) 2006 The Japanese Society of Applied Glycoscience

Award Address: The Award of Merit of the 2005's JSAG

\title{
Carbohydrate-active Enzymes from Extremophiles
}

(Received November 28, 2005)

Susumu Ito*

Creative Research Initiative 'Sousei' (CRIS), Hokkaido University (North-21, West-10, Kita-ku, Sapporo 001-0021, Japan)

\begin{abstract}
The term "extremophiles" is used for organisms that thrive under extreme conditions, and are designated the enzymes that are active and tolerant under extreme reaction conditions "extremozymes”. We have long been engaged in the screening, gene cloning, and industrial applications of alkaline enzymes from alkaliphilic bacilli. Alkaliphilic bacilli have made a great impact on the detergent industry, because they often produce alkaline enzymes that improve the detergency of detergents. We isolated a number of alkaline enzymes from alkaliphiles, such as cellulase, $\alpha$-amylase, protease, mannanase, and pectate lyase. We incorporated an alkaline cellulase into super-compact detergents for the first time in the world. Some of the alkaline enzymes were crystallized, and their tertiary structures were determined. The alkaline adaptation mechanism of these enzymes was analyzed by determination of the amino acid substitutions that and deletions occur during the alkaline adaptation process. The alkaline adaptation appeared to be a remodeling of ion pairs so that the charge balance is kept in the high alkaline $\mathrm{pH}$ range.
\end{abstract}

Key words: alkaliphiles, Bacillus, cellulase, amylase, pectate lyase, detergent enzyme, adaptation

\section{極限環境微生物が生産する糖質関連酵素に関する研究**}

\section{伊藤 進 $^{*}$}

北海道大学創成科学共同研究機構（001-0021 札幌市北区北 21 条西 10 丁目）

好アルカリ性細菌は，高い $\mathrm{pH}$ で生育できる微生物の総 称である。これらの微生物は, アルカリの温泉, 湖, 地下 熱水中に生息している場合も多いが，意外なことに何の変 哲もない身の回りの土壌や動植物から簡単に分離できる. おそらく, 自らアルカリ性物質を生産し, 周りの環境をア ルカリにして生存 (増殖)しているためである. Naイオ ンを必要とする好アルカリ性細菌（Naイオンが存在する と中性で生育できる）とアルカリでしか生育できない絶対 的好アルカリ性細菌に大別される。これらの好アルカリ性 微生物は多種多様のアルカリ性酵素を菌体外に分泌する. 極限環境微生物（extremophiles）とは，文字通り極限環境 で生育する微生物である。例えば，現在のところ，温度 $-10-121^{\circ} \mathrm{C}, \mathrm{pH} \quad 0.5-12.5$, 圧力 $100 \mathrm{MP}(1000$ 気圧）の範 囲で生息（生育）する微生物などが知られている。然しな がら, 最も工業的に利用されている extremophiles の酵素 (extremozymes) は好アルカリ性 Bacillus 由来である。

世界の工業用酵素市場は約 1800 億円，日本で 200 億円 前後と推定され，意外と思われるが洗剤用酵素が約 $40 \%$ 前後を占めている。洗浄水が高アルカリ性（pH 10～< 11） に設定されており，洗浄促進成分として，高アルカリで作 用するプロテアーゼ，セルラーゼ，アミラーゼ，ペクチ ナーゼ，マンナナーゼなどが配合されているからである.

\footnotetext{
${ }^{*}$ Tel \& Fax. +81-11-707-9286, E-mail: sito@cris.hokudai.ac.jp **平成 17 年度日本応用糖質科学会学会賞受賞講演
}

洗剂用酵素の研究はまさにニューバイオの集約ともいえる が，一般の人達には身近過ぎて見落とされている. 我々 は，ここ20 年以上極限環境微生物が生産する多数の工業 用酵素スクリーニングとその開発研究を行ってきた。分離 酵素の由来は，高アルカリ，高熱，低温，深海，地殼内な どの極限環境微生物群である。本稿では，酵素化学的性質 や立体構造的に興味深いアルカリ酵素について概説する. また，工業的に多用されているアルカリ酵素が何故アルカ リ環境に適応して来たかについて，その立体構造から推定 する.

なお，本研究は本誌を含めて詳細に縓めてあるので1-6), それらを参考にして頂ければ幸いである。

\section{1. アルカリセルラーゼ}

我々は，アルカリセルラーゼ K (CFD, endo-1,4- $\beta$-glucanase）を日本の洗剤に世界で初めて配合した。本酵素は 洗浄性が高く, Bacillus sp. KSM-635 株のアルカリ液体培 養で工業生産されている. CFDは菌体外酵素としては最 適温度が低く $\left(40^{\circ} \mathrm{C}\right)$, 水道水などで比較的低温洗浄する 日本の習慣に適合している。本酵素は, 各種界面活性剂, キレート剤，プロテアーゼなどの洗荗成分にも耐性があ り，最も特徵的なことは結晶性セルロースにほとんど作用 しない。衣服を CFD 配合洗剤で洗ってもボロボロになら ないのはこの性質があるからである。澱粉やタンパクの污 れは繊維の表面に存在するが，頑固な污れは木綿繊維の非 
晶部に閉じ込められている。使用前と着用後の木綿肌着を CFD 存在下で洗濯した後，オスミウム染色して単繊維断 面を顕微鏡観察すると, CFDによる洗浄効果が確認でき る。また, 着古した木綿肌着に CFDを入れて繰り返し洗 浄すると肌着中の残脂量が減少し白さが増す。CFD 配合 洗剂で木綿肌着を 100 回繰り返し洗濯しても重量の損失, 引っ張り強度, 纎維の重合度とフィブリル化度（毛羽立ち の尺度）の低下などはほとんど認められない22. CFD 配合 重質洗剂は, 従来品の $1 / 4$ の大きさに小型化されて商品化 されたが, 世界の洗剂市場の $60 \%$ 以上がこの種の超小型 化洗劑として普及している。その後, CFD より耐熱性の ある高アルカリ性の Egl-647) S-237 ${ }^{8}$ などを発見した．現 在, 組換え S-237 が工業生産され, 重質洗剂に配合されて いる6).

S-237は Egl-64よりも耐熱性が高い. 既に, 我々は CFD（941 アミノ酸；約 $105 \mathrm{kDa}$ ）の N-末端側と C-末端側 を欠失させた小型化酵素（約 $40 \mathrm{kDa}$ ，Ala 228-Leu 584）の 結晶構造を解明している9).この結晶構造を鋳型にしたホ モロジーモデリングとのキメラ酵素の結果から, Egl-64の 特異的アミノ酸 2 残基を Lys に置換すると, 付近に存在す る酸性アミノ酸残基と $\alpha$-ヘリックス $(\alpha 5)$ の両末端でイ オンペアを形成し，ほほS-237 と同等の耐熱化ができるこ とを証明した.このイオンペアが歪のあるへリックス $(\alpha-5)$ の両端をクリップで止めるようにして立体構造を耐熱化し ている ${ }^{10}$.

一方, 酵素の耐熱性と耐アルカリ性の進化論的な獲得機 構は全く異なる。例えば，中性セルラーゼとアルカリセル ラーゼ CFD を比較してみると, His 333 は活性部位に存在 し, His 333 の $\mathrm{N}^{\varepsilon 2}$ と nucleophile な Glu 373 の $\mathrm{O}^{\varepsilon 2}$ 原子間距 離は, $4.5 \AA$ である。その His 333 の $\mathrm{N}^{\varepsilon 1}$ と Glu 299 の $\mathrm{O}^{\varepsilon 2}$ 間でイオンペアを形成し安定化される (Fig. 1). 更に，ア ルカリ適応過程で獲得されたと考えられる四つの Arg 残 基が CFD 内に存在し，その中で $\operatorname{Arg} 423$ と Asp 235 およ びA Arg 464 とAsp 429 はそれぞれイオンペアを形成してい
る。また，Arg 567 およびAsp 503 も新たにイオンペア形 成を獲得している，その一方で，Lys-Aspのイオンペアは 至る所で解消されていることがわかる9．同様な進化は高 アルカリプロテアーゼ（M-protease）でも生じており，同 様な置換によってイオンネットワークが新たに形成されて いる11).

すなわち，アルカリ適応の過程は Arg と His の増加と Lys の減少に鍵がありそうである。その解釈は難しいが, 中性の酵素がアルカリ環境下に曝されたとき，その酵素の 表面上で何らかの適応を迫られたことは容易に推定され る.「何とか酵素タンパク質の表面を取り繥って倰ごう」 としたのは想像に難くない.アルカリ適応しょうとして酵 素が取った手段は，Lysを捨て，Arg と His を獲得して新 たなイオンネットワークを形成し，イオンペアのリモデリ ングを図ったのだろう。そして，アルカリ環境下で酵素の チャージバランスを保ったのである,111.アルカリ側では Lys よりも Arg と His はイオン化して抢り, 他の酸性アミ ノ酸とイオンペアがつくり易いのでアルカリで安定な構造 になるように進化していったと推定される,11).

\section{2. アルカリアミラーゼ}

$\alpha$-アミラーゼは， 食品・澱粉工業に必須の酵素である。 欧米では, 自動食器洗浄機の普及率が約 50\% で, 液化型 $\alpha$-アミラーゼ配合衣料用洗剂も販売されているため需要 が多い。世界の衣料と自動食器用洗剂のアミラーゼは食品 加工全体の生産量（額）に匹敵する，功，高アルカリ 領域で活性の高い液化型 $\alpha$-アミラーゼはなかった。工業 用酵素として需要が高い酵素は, 中性菌の Bacillus licheniformis が生産する最適 $\mathrm{pH}$ が 6.5 前後の液化型 $\alpha$-アミラー ゼ（BLA）である. BLA は, Bacillus stearothermophilus や Bacillus amyloliquefaciens の酵素と較ベアルカリ側で活性

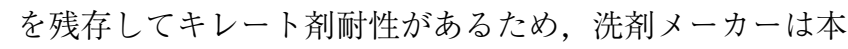
酵素を洗剂に配合してきた．欧米では洗濯機や自動食器洗 浄機は高温で $\left(40-60^{\circ} \mathrm{C}\right.$ 前後 $)$ 高アルカリ（pH 10 以上）

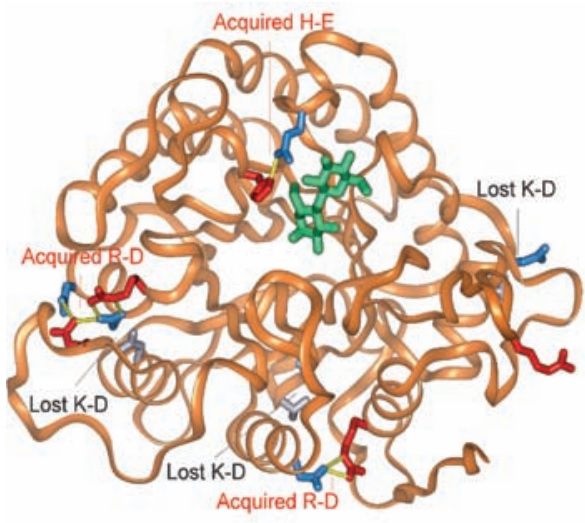

Alkaline cellulase K (CFD)

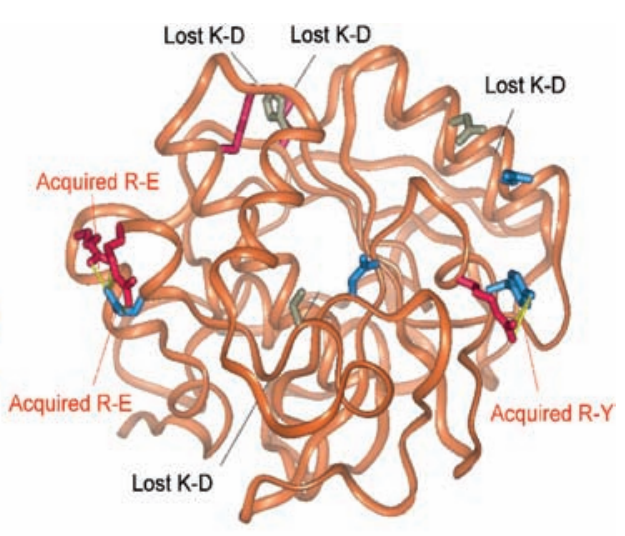

High-alkaline M-protease

Fig. 1. Local interactions introduced in the alkaline adaptation process.

Spatial distribution of the acquired Arg and His residues (red) and eliminated Lys residues (gray) responsible for the ion pair remodeling in CFD are shown (left). Shown in blue are the negatively charged residues that form an ion pair with the Arg, His or Lys residues. The cellobiose molecule is shown in green, and hydrogen bonds are in yellow. Similar alkaline adaptation by an ion pair remodeling of M-protease is also shown on the right. 
に設定されているので, 酵素の最適活性が高温と高アルカ リにあり耐キレート剂耐性がある必要があった5).

我々は，アルカリに最適 $\mathrm{pH}$ を有する好アルカリ性 $B a$ cillus 由来の液化型の $\alpha$-アミラーゼ（AmyK や AmyK 38） を発見し, 酵素化学的性質, 遺伝学的性質, タンパク工学 的改変の研究を進めてきた ${ }^{12-19)}$. 特に AmyK 38 の極めて特 徵的な性質は，全く $\mathrm{Ca}$ を含まないことである ${ }^{17)}$ (Fig. 2). 一般に，BLAのような $\alpha$ アアミラーゼは立体構造維持のた めに 3 個の $\mathrm{Ca}$ を含んでいるが, AmyK 38 は Ca と配位す るアミノ酸の多くが他のアミノ酸に置換しており $\mathrm{Na}$ だけ が配位できる立体構造になっていることが判明した20). AmyK 38 に Ca が存在しないのでキレート用耐性があり, 立体構造維持の機構は従来の酵素と全く異なっていた。

何故 Ca を含まない AmyK 38 が進化の過程で出現した のだろうか? 一般に, アルカリ環境, 特に $\mathrm{Na}$ が過飽和に なっている環境では 2 価の陽イオン $(\mathrm{Ca}$ や $\mathrm{Mg}$ ) が極端に

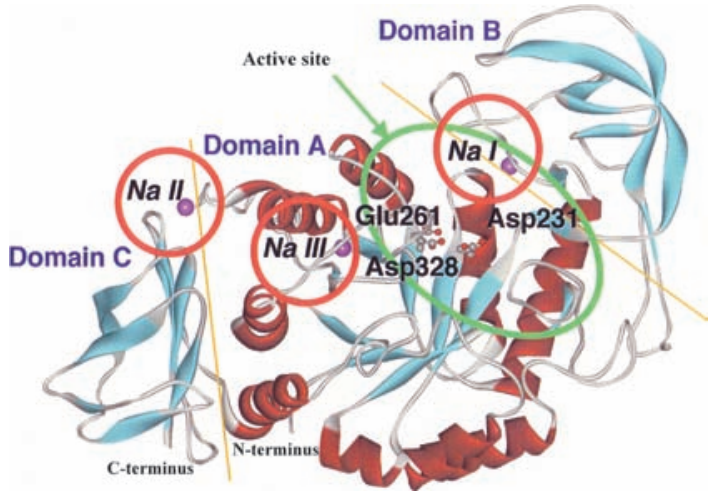

Fig. 2. The crystal structure of a calcium-free $\alpha$-amylase from an alkaliphilic Bacillus isolate.

The crystal structure of calcium-free AmyK 38, which resists chelating reagents, is shown. Its main chain folding is almost homologous to that of B. licheniformis, including the residues of active site. However, neither highly conserved $\mathrm{Ca}$ ions, which are located at the interface among domains $\mathrm{A}$ and $\mathrm{B}$ and domains $\mathrm{B}$ and $\mathrm{C}$, nor any other $\mathrm{Ca}$ ions appeared to exist in the molecule. Instead, three $\mathrm{Na}$ ions ( $\mathrm{Na} \mathrm{I}, \mathrm{NaII}$ and $\mathrm{NaIII}$ ) were found, and these are located at the positions corresponding to those of highly conserved $\mathrm{Ca}$ ions of other $\alpha$-amylases.
少ない. AmyK 38 はそのような環境で生き延び，Ca がな くてもアルカリで立体構造を維持しながら作用するように 進化してきた可能性がある。酵素のアルカリ適応のもう一 つの側面であろう. 当初, アーキアの耐熱アミラーゼも $\mathrm{Ca}$ を含まないと報告されたが，最近訂正されて $\mathrm{Ca}$ 含有酵 素であることが判明しているので，耐熱性と耐アルカリ性 は異なった進化過程を経てきたのは間違いない。

\section{3. アルカリペクチン酸リアーゼ}

本酵素は, 酸性多糖ポリガラツクロン酸を $\beta$-脱離反応 して不飽和オリゴガラツクロン酸を生成する ${ }^{21)}$. 我々は, 好アルカリ性 Bacillus 由来のアルカリペクチン酸リアーゼ Pel-15を分離して酵素化学的性質と立体構造を決定し た ${ }^{22)}$. Pel-15は, 平行 $\beta$-シートからなる $\beta$-ヘリックスとい う特異的な構造をしている (Fig. 3). 従来知られていた中 性の酵素23,24) と異なり，活性部位周辺を覆うループが 1 本 しかなく， $\beta$-ヘリックスの $\mathrm{N}$-末端と C-末端を保護する ループも全く存在しない. 複雑な構造を有する酵素とは耐 熱性がさほど変わらないので，余分な構造を削ってしまっ たのも過酷なアルカリ環境での不安定さを解消しようとし てコンパクト化した可能性がある。また，CFD やM-protease 同様, Pe-15の 1 分子あたりの Arg 含量も高い.

さらに，中性溶液中で Pel-15 を結晶化すると Ca は 1 個 しか酵素分子中には存在せず，活性もほとんどない。しか し，アルカリ（pH 9.5）で結晶化すると， Glu 83，Asp 63 とAsp 84 は方向を変え新たに Ca 補足し安定化するよう になる（Fig. 4)。また，これらのアミノ酸は活性部位近傍 にあるため， $\mathrm{Ca}$ で安定化することによって基質結合部位 を形成し酵素活性自体もアルカリ側で飛躍的に促進され る。アルカリ適応としては極めて興味深い性質である。

酵素がアルカリ適応(進化)でたどった道は多様である. 最近, 数株の好アルカリ性細菌のゲノムが解読されたが, 中性菌が何故好アルカリ性細菌になったのかさえ詳しくは 解明されていない．然しながら，アルカリ酵素の立体構造

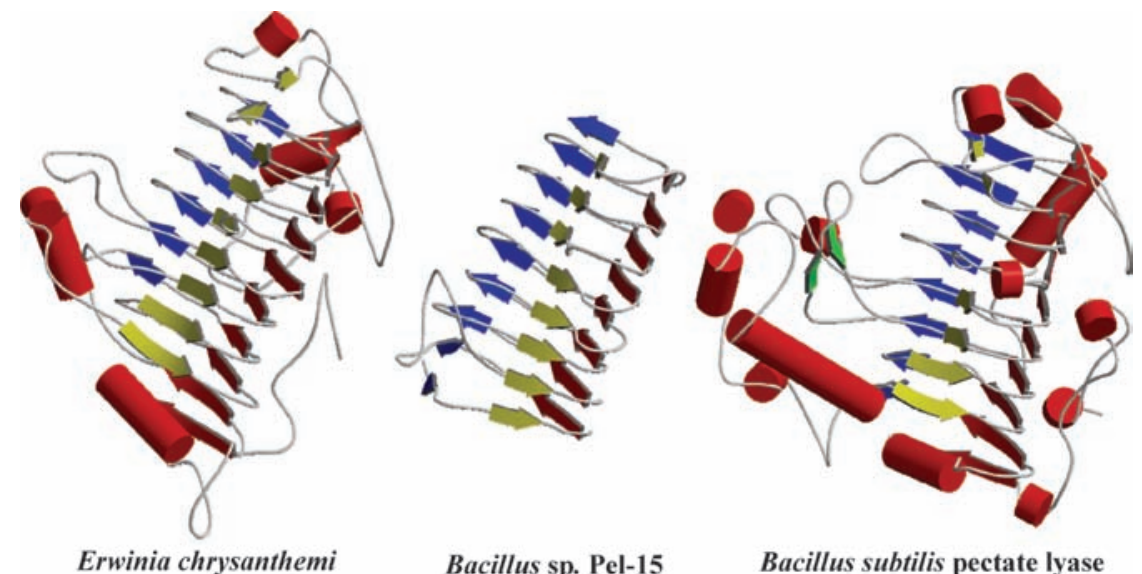

pectate lyase $\mathrm{C}$

Fig. 3. The crystal structure of a high-alkaline, low-molecular-weight pectate lyase, Pel-15.

Compared with pectate lyases from Erwinia crysanthemi ${ }^{23)}$ (left) and Bacillus subtilis ${ }^{24)}$ (right), the overall structure of Pel-15 is a very simple eight-turn, right-handed parallel $\beta$-helix domain with one loop protruding from one side of the helix and without $\mathrm{N}$ - and $\mathrm{C}$-terminal extensions (center). 


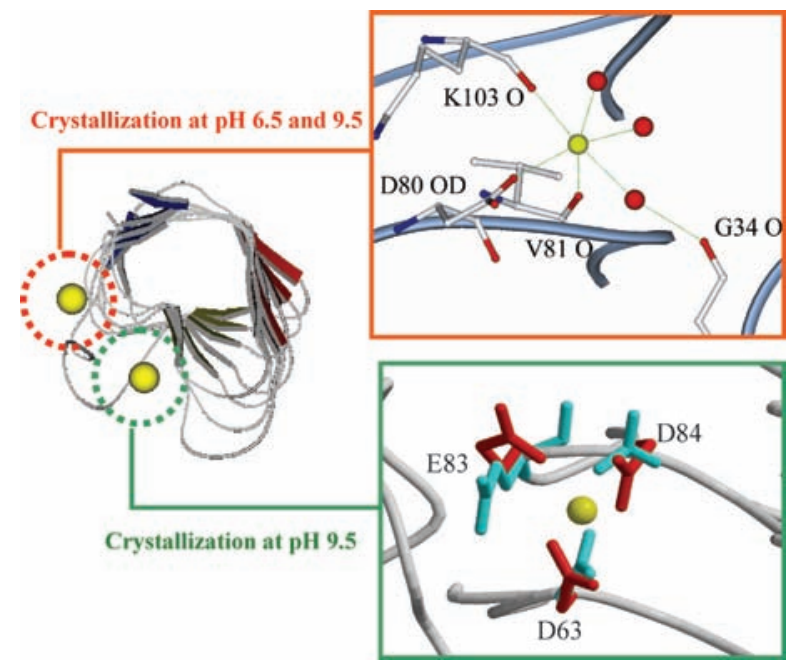

Fig. 4. Additional $\mathrm{Ca}$ binding site in Pel-15 acquired at alkaline $\mathrm{pH}$.

When Pel-15 was crystallized at both $\mathrm{pH} 6.5$ and 9.5, the enzyme contained one $\mathrm{Ca}$ ion (yellow ball) in the structure coordinated with Asp 63, Glu 83, and Asp 84 (orange). Water molecules are shown in red balls. However, raising the $\mathrm{pH}$ to 9.5 (green) resulted in the binding of an additional $\mathrm{Ca}$ ion by spatial change of Gly 34, Asp 80, Val 81, and Lys 103 from pH 6.5 (cyan) to 9.5 (red). The common $\mathrm{Ca}$ ion found in the structures at both $\mathrm{pHs}$ appeared to stabilize the whole protein. The additional $\mathrm{Ca}$ ion found at $\mathrm{pH} 9.5$ may neutralize the acidic substrate, polygalacturonate. The region around the additional $\mathrm{Ca}$ ion seems to bind to the substrate, thereby stimulating the lyase activity at alkaline $\mathrm{pH}$ range.

を解析すると，単純なプロセスでアルカリ適応してきたの ではないことだけは明白である。生物進化はそのときの環 境に合わせて適応できたものだけが生き残っただけに過ぎ ない。「偶然」が或る生物を絶滅し，「偶然」が或る生物を 生き残した，その本質は，タンパク質の偶然的変異が遺伝 子レベルで起こった反映に過ざない。酵素のアルカリ適応 も多様なプロセスをたどって現在に至ったと考えた方が自 然な解釈といえる.

\section{4. 工業用酵素の大量生産}

工業用酵素の市場価格は異常に安価である．特に洗剂用 酵素の場合, 突然変異法や遺伝子組換え法であれ, 菌体外 に数 $\mathrm{g} / \mathrm{L}$ から $30 \mathrm{~g} / \mathrm{L}$ の生産性が要求される. 安価な大量 消費財である洗剂に酵素を配合するためには，ニューバイ 才技術の粋を集約させなければならない。遺伝子組換え法 が必ずしも高生産性を約束するものではないが，酵素改良 が手作り（テイラーメイド）であったので，本手法を使用 せざるを得なかった，そのきっかけは，読者からすれば些 細な研究から始まった ${ }^{25,26}$. 後述の謝辞にある研究仲間が, その後の研究を発展させてくれた．私は彼らの研究に学 び, 本研究のほとんどを組換え酵素を用いて大量生産, 改 変, 酵素の作用機構や立体構造解析に供した。

最後に，私のささやかな意見を記しておきたい. 現在， 生物多様性条約などの制約から，我国は遺伝（生物）資源 の確保に大きな遅れをとっている．如何にニューバイオが 脚光を浴びているにせよ, 我々は「スクリーニング」によ る遺伝資源収集に注力すべく研究を進めてきた。我国は農
業，畜産，海洋(水産)立国である。その優位性を認識し， そこから新たな（微）生物遺伝資源を確保して行かねばな らないだろう。私は，身の回りの「スクリーニング」に回 帰することこそが, 我国のバイオ研究発展の鍵があると信 じている.

本学会の学会賞を頂いたことは, 身に余る光栄である. 学会賞にご推薦頂いた, 東日本支部長の春見隆文さんと北 海道支部長の松井博和さんに深くお礼申し上げる. 松井博 和さんは, 学生時代から切碰环磨しあった共同研究者でも ある. 本研究は, 主として花王株式会社の生物科学研究所 で行ったものである。研究仲間(戦友)に支えられた私は, 世界で最も幸せな研究者である。川合修二，小林 徹，尾 崎克也, 荒勝 俊, 佐伯勝久, 萩原 浩, 五十嵐一暁, 袴 田佳宏, 影山 泰, 四方資通, 人見 潤, 小池謙造, 武井 章, 住友伸行, 滝川博文, 奥田光美, 久保田浩美, 押野一 志, 林 康弘, 大田裕一, 足立重人, 秋山美子, 佐藤朋 一, 秦田勇二, 吉松 正, 河南俊朗, 小澤忠弘, 森 啓，（故）下岡正治，荒木裕行，北村香織，高岩美喜雄， 上村隆明，澤田和久，小川晃範，斉藤和広，涼松 淳，檜 坦紀彦さんを始めとする数多くの方達の成果である，会社 時代の研究仲間を書き切れないが，参考論文の著者をご覧 頂ければ幸いである。また，中川弘美会長は，バイオの素 人集団だった我々に発酵タンクを含めた酵素の自社生産を 最後まで支援してくれた。

各種酵素の立体構造解析は, 名古屋大学の山根 隆, 白 井 剛, 鈴木淳夫と秋田昌岳さん, 京都大学の三木邦夫と 野中 剛さん, SPring-8 の植木龍夫と山本雅貴さん, 東京 農工大学の坂野好幸と殿塚隆史さんとの共同研究である. 酵素の NMR 解析は, 東京大学の島田一郎と新田洋治さん の協力を得た. 酵素化学的性質の研究は, 静岡大学の岡田 厳太郎さん, 信州大学の神田鷹久さんのグループ, 鹿児島 大学の竹田靖史さん, 海洋研究開発機構の掘越弘毅, 出口 茂, 高井研と能木裕一さん, Leicester University (UK) の William D. Grant さん, 東洋大学の宇佐美論と武田信博さ ん，日本食品化工秼)の中久喜輝夫と小川浩一さんとの共同 研究である (共同研究者の所属は, 全て研究当時のもので す．役職等は省略させて頂きました).

\section{文献}

1 ) S. Ito: Alkaline cellulases from alkaliphilic Bacillus: enzymatic properties, genetics, and application to detergents. Extremophiles, 1, 61-66 (1997)

2 ) E. Hoshino and S. Ito: Application of alkaline cellulases that contribute to soil removal in detergents. in Enzymes in Detergency, J.H. van Ee O. Misset and E. J. Baas., eds., Marcel Dekker, lnc., New York, pp. 149-174 (1997).

3 ) S. Ito, T. Kobayashi, K. Ara, K. Ozaki, S. Kawai and Y. Hatada: Alkaline detergent enzymes from alkaliphiles: enzymatic properties, genetics, and, structures. Extremophiles, 2, 185-190 (1998).

4 ) 伊藤進, 小林 徹, 尾崎克也: 洗剂用酵素の開発. $J$. 
Appl. Glycosci., 47, 243-251 (2000).

5 ) K. Igarashi, H. Hagihara and S. Ito: Protein engineering of detergent $\alpha$-amylases. Trends Glycosci. Glycotechnol., 15, 101114 (2003).

6 ) S. Ito, T. Kobayashi, Y. Hatada and K. Horikoshi: Enzymes in modern detergents: microbial enzymes and biotransformations. in Methods Biotechnol., J.L. Barredo, ed., Vol. 17, The Humana Press Inc., Totowa, pp. 151-163 (2005).

7 ) S. Shikata, K. Saeki, H. Okoshi, T. Yoshimatsu, K. Ozaki, S. Kawai and S. Ito: Alkaline cellulases for laundry detergents: production by alkalophilic strains of Bacillus and some properties of the crude enzymes. Agric. Biol. Chem., 54, 91-96 (1990).

8 ) Y. Hakamada, K. Koike, T. Yoshimatsu, H. Mori, T. Kobayashi and S. Ito: Thermostable alkaline cellulase from an alkaliphilic isolate, Bacillus sp. KSM-S237. Extremophiles, 1, 151156 (1997).

9 ) T. Shirai, H. Ishida, J. Noda, T. Yamane, K. Ozaki, Y. Hakamada and S. Ito: Crystal structure of alkaline cellulase K: insight into the alkaline adaptation of an industrial enzyme. $J$. Mol. Biol., 310, 1079-1087 (2001).

10) T. Ozawa, Y. Hakamada, Y. Hatada, T. Kobayashi, T. Shirai and S. Ito: Thermostabilization by replacement of specific residues with lysine in a Bacillus alkaline cellulase: building a structural model and implications of newly formed double intrahelical salt bridges. Protein Eng., 14, 501-504 (2001).

11) T. Shirai, A. Suzuki, T. Yamane, T. Ashida, T. Kobayashi, J. Hitomi and S. Ito: High-resolution crystal structure of Mprotease: phylogeny aided analysis of the high-alkaline adaptation mechanism. Protein Eng., 10, 627-634 (1997).

12) K. Igarashi, Y. Hatada, K. Ikawa, H. Araki, T. Ozawa, T. Kobayashi, K. Ozaki and S. Ito: Improved thermostability of a Bacillus $\alpha$-amylase by deletion of an arginine-glycine residue is caused by enhanced calcium binding. Biochem. Biophys. Res. Commun., 248, 372-377 (1998).

13) K. Ikawa, H. Araki, Y. Tsujino, Y. Hayashi, K. Igarashi, Y. Hatada, H. Hagihara, T. Ozawa, K. Ozaki, T. Kobayashi and S. Ito: Hyperexpression of the gene for a Bacillus $\alpha$-amylase in Bacillus subtilis: enzymatic properties and crystallization of the recombinant enzyme. Biosci. Biotechnol. Biochem., 62, 17201725 (1998).

14) K. Igarashi, Y. Hatada, H. Hagihara, K. Saeki, M. Takaiwa, T. Uemura, K. Ara, K. Ozaki, S. Kawai, T. Kobayashi and S. Ito: Enzymatic properties of a novel liquefying $\alpha$-amylase from an alkaliphilic Bacillus isolate and entire nucleotide and amino acid sequences. Appl. Environ. Microbiol., 64, 3282-3289 (1998).

15) K. Igarashi, T. Ozawa, K. Ikawa-Kitayama, Y. Hayashi, H. Araki, K. Endo, H. Hagihara, K. Ozaki, S. Kawai and S. Ito: Thermostabilization by proline substitution in an alkaline, liquefying $\alpha$-amylase from Bacillus sp. strain KSM-1378. Biosci. Biotechnol. Biochem., 63, 1535-1540 (1999).

16) H. Hagihara, K. Igarashi, Y. Hayashi, K. Endo, K. Ikawa-Kitamura, K. Ozaki, S. Kawai and S. Ito: Novel $\alpha$-amylase that is highly resistant to chelating reagents and chemical oxidants from the alkaliphilic Bacillus isolate KSM-K 38. Appl. Environ. Microbiol., 67, 1174-1750 (2001).

17) H. Hagihara, Y. Hayashi, K. Endo, K. Igarashi, T. Ozawa, S. Kawai, K. Ozaki and S. Ito: Deduced amino-acid sequence of a calcium-free $\alpha$-amylase from a strain of alkaliphilic Bacillus. Implications from molecular modeling of high oxidation stability and chelator resistance of the enzyme. Eur. J. Biochem., 268, 3974-3982 (2001)

18) S. Ito, Y. Hatada, T. Ozawa, H. Hagihara, H. Araki, Y. Tsujino, K. Kitayama, K. Igarashi, Y. Kageyama, T. Kobayashi and K. Ozaki: Protein-engineered Bacillus $\alpha$-amylases that have acquired both enhanced thermostability and chelator resistance. J. Appl. Glycosci., 49, 257-264 (2002).

19) H. Hagihara, K. Igarashi, Y. Hayashi, K. Kitayama, K. Endo, T. Ozawa, K. Ozaki, S. Kawai and S. Ito: Improvement of thermostability of a calcium-free $\alpha$-amylase from an alkaliphilic Bacillus sp. by protein engineering. J. Appl. Glycosci., 49, 281-289 (2002).

20) T. Nonaka, M. Fujihashi, A. Kita, H. Hagihara, K. Ozaki, S. Ito and K. Miki: Crystal structure of calcium-free $\alpha$-amylase from Bacillus sp. strain KSM-K 38 (AmyK 38) and its sodium binding sites. J. Biol. Chem., 278, 24818-24824 (2003).

21) Y. Hatada, K. Saito, K. Koike, T. Yoshimatsu, T. Kobayashi and S. Ito: Deduced amino-acid sequence and possible catalytic residues of a novel pectate lyase from an alkaliphilic strain of Bacillus. Eur. J. Biochem., 267, 2269-2275 (2000).

22) M. Akiata, A. Suzuki, T. Kobayashi, S. Ito and T. Yamane: The first structure of pectate lyase belonging to polysaccharide lyase family 3. Acta Crystallogr., D 57, 1786-1792 (2001).

23) M.D. Yoder, N.T. Keen and F. Jurnak: New domain motif: the structure pectate lyase $\mathrm{C}$, a secreted plant virulence factor. Science, 260, 1503-1507 (1993).

24) R. Pickersgill, J. Jenkins, G. Harris, W. Nasser and J. RobertBaudouy: The structure of Bacillus subtilis pectate lyase in complex with calcium. Nat. Struct. Biol., 1, 717-723 (1994).

25) N. Sumitomo, K. Ozaki, S. Kawai and S. Ito: Nucleotide sequence of the gene for an alkaline endoglucanase from an alkalophilic Bacillus and its expression in Escherichia coli and $\mathrm{Ba}$ cillus subtilis. Biosci. Biotechnol. Biochem., 56, 872-877 (1992).

26) N. Sumitomo, K. Ozaki, J. Hitomi, S. Kawaminami, T. Kobayashi, S. Kawai and S. Ito: Application of the upstream region of a Bacillus endoglucanase gene to high-level expression of foreign genes in Bacillus subtilis. Biosci. Biotechnol. Biochem., 59, 2172-2175 (1995). 